\title{
Impact of introducing near patient testing for standard investigations in general practice
}

\author{
Elizabeth Rink, Sean Hilton, Ala Szczepura, Joy Fletcher, Bonnie Sibbald, Carol Davies, \\ Paul Freeling, John Stilwell
}

Division of General Practice and Primary Care, St George's Hospital Medical School, London SW17 0RE

Elizabeth Rink, research fellow

Sean Hilton, senior lecturer Bonnie Sibbald, senior research fellow

Paul Freeling, professor of general practice and primary care

Health Services Research Unit, University of Warwick, Coventry CV4 7AL

Ala Szczepura, principal research fellow

Joy Fletcher, research fellow Carol Davies, research fellow John Stilwell, director

Correspondence to: Professor Hilton.

BMf 1993;307:775-8

\section{Abstract}

Objective-To assess the clinical and economic impact of surgery based near patient testing in general practice for six commonly used biochemical and bacteriological tests.

Design-After four months' monitoring, equipment for two bacteriological and four biochemical tests was introduced without cost into 12 practices using a crossover design. Structured request forms were used to monitor laboratory investigations.

Setting-12 general practices in west midlands and south west Thames with list sizes above $\mathbf{9 0 0 0}$.

Main outcome measures-Investigation rates per 1000 consultations. Changes from baseline rates. Reasons for requesting investigations and provisional diagnoses. Cost per test and sensitivity of costs to rate of use.

Results-Investigation rates for the six tests rose by $16 \cdot 5 \%$ (from $78 \cdot 6 / 1000$ consultations to $91 \cdot 6 / 1000$ ) when equipment was available in the surgery and reverted to baseline rates when it was withdrawn. The average weekly number of tests when equipment was available ranged from 0.5 to 10.5 (mean 9.0). Cholesterol tests were used as an addition to laboratory testing, usually for screening. Midstream urine analysis was often done in the surgery instead of in the laboratory, although $30 \%$ of samples were tested by both methods. Doctors' reasons for investigation and conditions tested were largely unaffected by availability of surgery tests. Costs for surgery tests were higher for all tests except midstream urine.

Conclusions-Availability of surgery based testing increased the number of tests performed. It was cost effective only for midstream urine analysis.

\section{Introduction}

Equipment for carrying out diagnostic tests in general practice surgeries (near patient testing) has become increasingly available over the past decade. ${ }^{1}$ Use of such equipment needs to be evaluated ${ }^{23}$ to prevent it being adopted merely because it exists rather

\section{Equipment for near patient testing}

Test

Equipment

Manufacturer

Cholesterol

Haemoglobin $\gamma$-Glutamyltransferase

Electrolytes (sodium and potassium)

Midstream urine

Nova 1 ion analyser

Boehringer Mannheim, Lewes

Chlamydia

Clinitek 10 with

Multistix 8SG

Clearview vaginal

Chlamydia test kit than because it has been shown to be cost effective. ${ }^{47}$ We have evaluated the uptake and impact on investigation patterns, reasons given for testing by general practitioners, conditions investigated, and impact on patient care and costs of six near patient tests in British general practices.

\section{Methods}

During June 1989 to December 1991 we studied 12 group practices representative of primary care in a range of settings from inner London to relatively isolated rural areas. The box lists the machines and tests evaluated. Equipment was introduced at no cost to the practices and general practitioners and nurses were fully trained. We analysed use of laboratory tests in the four months before the equipment was introduced. Biochemistry equipment was given to six practices and bacteriological equipment to the other six. After six months the equipment was swapped over for a further nine months. The additional three months were used to study patient care in more detail.

Use of laboratory and surgery based tests and numbers of consultations were recorded throughout. A specially designed form was used which included standard information on patients plus details of provisional diagnosis and the reason for requesting the test (to monitor an existing condition, assist diagnosis, screen in presence of risk factors, or on patient demand).

We calculated cost per near patient test, including capital costs, other fixed costs (maintenance and cost of quality assurance), and variable costs (staff, consumables, and phlebotomy). Comparable costs of laboratory tests were measured in up to 100 laboratories throughout Britain and a mean cost calculated which was weighted by throughput. A sample of patients completed questionnaires to measure costs not associated with performance of the tests such as patient time, transport, and employment costs. Costs of tests were combined with uptake patterns to estimate practices' investigation costs.

During the final three months of the study we examined in detail the impact on patient care of two tests (cholesterol and midstream urine analysis). The tests were chosen because of their high uptake and clinical relevance. The notes of a random sample of 150 patients who had tests in the surgery were examined for clinical history, prescribing, referrals, and recording of risk factors. They were compared with those of control patients from the same practice receiving a comparable laboratory test when surgery based testing was not available (longitudinal comparison) and those of control patients from practices without surgery based testing who had laboratory tests in the same period (cross sectional comparison). Controls were matched for age and sex. Cost effectiveness of surgery testing was compared with that of laboratory testing. ${ }^{8}$ 
Mean $\%$ change when NPT availablet

\begin{tabular}{|c|c|c|c|c|c|c|c|}
\hline & \multirow[b]{2}{*}{$\begin{array}{l}\text { Mean (range) } \\
\text { No of tests/ } \\
\text { week }\end{array}$} & \multirow[b]{2}{*}{$\begin{array}{c}\text { Mean (SD) \% } \\
\text { change from } \\
\text { baseline when } \\
\text { NPT } \\
\text { available }\end{array}$} & \multirow[b]{2}{*}{$\begin{array}{c}\text { Mean (SD) \% } \\
\text { change from } \\
\text { baseline when } \\
\text { NPT } \\
\text { not available* }\end{array}$} & \\
\hline & & & & Total & $\begin{array}{l}\text { Change due } \\
\text { to laboratory } \\
\text { tests only }\end{array}$ & $\begin{array}{l}\text { Change due } \\
\text { to NPT } \\
\text { only }\end{array}$ & $\begin{array}{l}\text { Change due } \\
\text { to both } \\
\text { NPT and } \\
\text { laboratory } \\
\text { tests }\end{array}$ \\
\hline Urea and electrolytes & $0.8(0-4 \cdot 4)$ & $1 \cdot 2(43 \cdot 3)$ & $-9.8(33.0)$ & $4 \cdot 6$ & $-7 \cdot 8$ & $7 \cdot 2$ & $5 \cdot 2$ \\
\hline Cholesterol & $3 \cdot 2(0 \cdot 6-10 \cdot 7)$ & $107(131 \cdot 4)$ & $30.5(63.4)$ & $88 \cdot 5$ & $-7 \cdot 1$ & $82 \cdot 1$ & 13.5 \\
\hline$\gamma$-Glutamyltransferase & $0.3(0-1 \cdot 7)$ & $29 \cdot 6(79 \cdot 6)$ & $-26 \cdot 1(45 \cdot 8)$ & $48 \cdot 4$ & $17 \cdot 9$ & $18 \cdot 6$ & 11.9 \\
\hline Full blood count/haemoglobin & $1 \cdot 7(0-4 \cdot 3)$ & $-0.2(30 \cdot 7)$ & $-6.9(22.7)$ & 1.4 & $-9 \cdot 4$ & 7.5 & $3 \cdot 3$ \\
\hline Midstream urine & $9 \cdot 2(1 \cdot 5-20 \cdot 8)$ & $21.9(41.7)$ & $-9.6(35.9)$ & $27 \cdot 2$ & $-39 \cdot 7$ & $37 \cdot 2$ & $29 \cdot 7$ \\
\hline High vaginal swab/chlamydia & $0.5(0-1.5)$ & $15.2(83.5)$ & $3.0(37.9)$ & -4.9 & $-20 \cdot 5$ & $7 \cdot 6$ & $8 \cdot 0$ \\
\hline
\end{tabular}

${ }^{\star}$ Change in mean number of tests/1000 consultation/practice. †Change in mean number of tests/1000 consultations pooled across all practices.

TABLE II-Reasons given by doctors for near patient (NPT) and laboratory tests *

\begin{tabular}{|c|c|c|c|}
\hline Test & $\begin{array}{c}\text { No (\%) of } \\
\text { laboratory tests }\end{array}$ & $\begin{array}{l}\text { No (\%) of } \\
\text { NPT }\end{array}$ & $\begin{array}{l}\text { Ratio of proportions } \\
\text { ( } 95 \% \text { confidence interval) }\end{array}$ \\
\hline \multirow{5}{*}{$\begin{array}{l}\text { Urea and electrolytes } \\
\text { Monitor } \\
\text { Diagnosis } \\
\text { Screening }\end{array}$} & 1673 & 228 & \\
\hline & $577(34)$ & $32(58)$ & $1.7(1.5$ to 1.9$)$ \\
\hline & $1028(61)$ & $85(37)$ & $0.6(0.5$ to 0.7$)$ \\
\hline & $68(4)$ & $11(5)$ & $1.2(0.6$ to 2.2$)$ \\
\hline & & $\chi^{2}=49.8 p<0.0001$ & \\
\hline Cholesterol & 962 & \multirow{2}{*}{958} & \\
\hline Monitor & $495(51)$ & & $0.3(0.3$ to 0.4$)$ \\
\hline Diagnosis & $260(27)$ & $140(15)$ & $0.5(0.4$ to 0.7$)$ \\
\hline Screening & $190(20)$ & $560(58)$ & $3.0(2.6$ to 3.4$)$ \\
\hline \multirow[t]{2}{*}{ Patient demand } & $17(2)$ & $74(8)$ & $4.7(2.7$ to 7.9$)$ \\
\hline & 273 & $\chi^{2}=396.7 \mathrm{p}<0.0001$ & \\
\hline \multirow{4}{*}{$\begin{array}{l}\gamma \text {-Glutamyltransferase } \\
\text { Monitor } \\
\text { Diagnosis } \\
\text { Screening }\end{array}$} & \multirow{2}{*}{$\begin{array}{r}84(31) \\
173(63)\end{array}$} & $31(36)$ & $1.2(0.8$ to 1.6$)$ \\
\hline & & $41(48)$ & $0.8(0.6$ to 0.9$)$ \\
\hline & \multirow[t]{2}{*}{$16(6)$} & $14(16)$ & $2.8(1.4$ to 5.4$)$ \\
\hline & & $\chi^{2}=11.8 p<0.003$ & \\
\hline \multirow{6}{*}{$\begin{array}{l}\text { Full blood count/haemoglobin } \\
\text { Monitor } \\
\text { Diagnosis } \\
\text { Screening } \\
\text { Patient demand }\end{array}$} & 4463 & 525 & \\
\hline & $1034(23)$ & $121(23)$ & $1.0(0.8$ to 1.2$)$ \\
\hline & $2881(65)$ & $321(61)$ & $0.9(0.9$ to 1.0$)$ \\
\hline & $532(12)$ & $77(15)$ & $1.2(1.0$ to 1.5$)$ \\
\hline & $16(0.03)$ & $6(1)$ & $3.2(1.3$ to 8.1$)$ \\
\hline & & \multirow{2}{*}{$x^{2}=10.3 p<0.02$} & \\
\hline Midstream urine & 2620 & & \\
\hline \multirow{4}{*}{$\begin{array}{l}\text { Monitor } \\
\text { Diagnosis } \\
\text { Screening }\end{array}$} & $355(14)$ & $146(7)$ & $0.5(0.4$ to 0.6$)$ \\
\hline & $2226(85)$ & $1650(80)$ & $0.9(0.9$ to 1.0$)$ \\
\hline & 39 (1) & 278 (13) & $9.0(6.5$ to 12.5$)$ \\
\hline & & \multirow[t]{2}{*}{$\chi^{2}=293.4 \mathrm{p}<0.0001$} & \multirow{6}{*}{$\begin{array}{l}0.8(0.3 \text { to } 1.8) \\
1.0(1.0 \text { to } 1.0) \\
2.9(0.7 \text { to } 11.3)\end{array}$} \\
\hline \multirow{5}{*}{$\begin{array}{l}\text { High vaginal swab/chlamydia } \\
\text { Monitor } \\
\text { Diagnosis } \\
\text { Screening }\end{array}$} & 837 & & \\
\hline & \multirow{2}{*}{$\begin{array}{c}44(5) \\
787(94)\end{array}$} & 146 & \\
\hline & & $137(94)$ & \\
\hline & $6(1)$ & $3(2)$ & \\
\hline & & $\chi^{2}=2.8 p<0.3$ & \\
\hline
\end{tabular}

${ }^{\star}$ Demand is not included when it accounted for less than $0.5 \%$.

\section{DATA ANALYSIS}

Coding of provisional diagnosis was based on the ninth International Classification of Disease. All data were analysed with the SPSS-PC package. We calculated investigation rates per 1000 consultations for each practice and the percentage change from baseline rates. We assessed whether observed changes in investigation rates were due to near patient tests being used as a substitute for laboratory tests or as an extra service, or both. Paired $t$ tests, unpaired $t$ tests, odds ratios, ratios of proportions ( $95 \%$ confidence interval), and $\chi^{2}$ tests were used as appropriate.

We analysed the effect of throughput on costs of surgery testing. For midstream urine analysis the following were also varied: increase in investigation rate with surgery testing (0-20\%), percentage of surgery tests followed by laboratory test (20-60\%), and percentage of positive test results $(20-40 \%)$.

\section{Results}

A total of 88523 consultations took place in the first four months. The request rate for all investigations during this baseline phase was $142 \cdot 7 / 1000$ consultations. For the six tests studied the rate was $78 \cdot 6 / 1000$. There was considerable variation among practices (44$132 / 1000$ ) and even greater variation among individual doctors (29-150/1000).

Rate of investigation for the six tests studied increased by $16 \cdot 5 \%$ from $78 \cdot 6 / 1000$ consultations at baseline to $91 \cdot 6 / 1000$ consultations when equipment was available in the surgery. When the same practices did not have the equipment the rates were virtually unchanged at $79 \cdot 4 / 1000$. Investigation rates for the other normally available biochemistry, haematology, and bacteriology tests did not change when practices had testing equipment. The average number of near patient tests done by each practice was nine a week (range $0 \cdot 5-10 \cdot 5$ for bacteriology tests and 4.5-7.0 for biochemistry tests). Test uptake was recorded over 299323 consultations (table I). Increases in cholesterol testing when near patient tests were available were almost entirely due to extra testing in the surgery. The number of midstream urine analyses done in the laboratory fell but these were replaced by near patient tests, with a net increase in tests. Almost a third (30\%) of analyses were done in both the surgery and the laboratory. The increase in $\gamma$-glutamyltransferase tests was due almost equally to near patient tests and increased laboratory tests. Other tests showed only small changes.

\section{REASONS FOR TESTING}

Table II shows the reasons for testing in the surgery compared with those for laboratory testing. For electrolytes, a near patient test was significantly more likely to be used than a laboratory test for monitoring and less likely to be used for diagnosis. For cholesterol, near patient tests were significantly more likely to be used for screening or because of patient demand and less likely to be used for monitoring or diagnosis than laboratory tests.

Few tests were performed for $\gamma$-glutamyltransferase, but when near patient testing was available it was more likely to be used for screening and less likely for diagnosis than laboratory testing. The near patient test for haemoglobin was used significantly more often than the equivalent laboratory test only for tests requested by patients. Analysis of midstream urine specimens in the surgery was used for screening more than laboratory tests, but the number of screening tests was small (accounting for less than $5 \%$ of tests) and the difference might be due to variations in recording.

The only significant change with time was for cholesterol requests. When the near patient test was not available the laboratory was used more for screening than it had been at baseline (ratio of proportions 1.6 , $95 \%$ confidence interval 1.3 to $2 \cdot 0$ ).

The diseases for which the tests were used did not show many changes. However $24.5 \%$ of electrolyte tests in the surgery were for heart and hypertensive disorders compared with $9.6 \%$ at baseline. Forty two per cent of near patient haemoglobin tests used for diagnostic purposes and $71 \%$ of those for monitoring were for anaemia as compared with $23.5 \%$ and $39 \%$ respectively at baseline. None of these changes was significant.

costs

Table III shows the costs of laboratory and surgery based tests for cholesterol and midstream urine. At the




observed throughput tests for $\gamma$-glutamyltransferase cost $£ 2.95$ in the surgery and $£ 1.62$ in the laboratory; costs for haemoglobin tests were $£ 3.62$ and $£ 2.69$ respectively. There were no significant differences between patients who had laboratory and surgery based tests in demographic details, means of travel, or employment status. Near patient test costs were higher per test than laboratory test costs for all tests except midstream urine. For cholesterol 130 tests a week were needed for surgery based testing to break even. However, inclusion of associated and patient costs reduced this figure to 16 .

At the throughputs observed at baseline, near patient cholesterol tests were calculated to increase a practice's costs for investigative tests by $£ 2350$ (SD $£ 50)$ a year and by $£ 1425(£ 625)$ if patient costs were included. With the observed increase in cholesterol investigations which occurred when near patient testing was introduced costs would rise by $£ 3260$ a year. Even in smaller practices increases in costs remained similar because of high fixed costs and lower throughputs.

For midstream urine the sensitivity analysis showed

TABLE III-Costs of near patient and laboratory tests at 1991 prices

\begin{tabular}{lcc}
\hline & $\begin{array}{c}\text { Cholesterol } \\
(£)\end{array}$ & $\begin{array}{c}\text { Midstream } \\
\text { urine }(£)\end{array}$ \\
\hline Performance costs in surgery: & & \\
5 Tests/week & 11.60 & 1.41 \\
10 Tests/week & 6.85 & 1.03 \\
20 Tests/week & 4.48 & 0.84 \\
50 Tests/week & 3.06 & 0.73 \\
Performance cost in laboratory & 2.48 & $2.84^{\star}$ \\
Total cost in surgerył: & & $5.76 \dagger$ \\
5 Tests/week & 11.87 & 2.50 \\
10 Tests/week & 7.12 & 2.12 \\
20 Tests/week & 4.75 & 1.93 \\
50 Tests/week & 3.33 & 1.82 \\
Total cost in laboratory & 5.32 & $5.32^{\star}$ \\
& & $8.24 \dagger$ \\
\hline
\end{tabular}

*Cost for negative sample. + Cost for positive sample.

$\mp$ Cost including system costs (mainly staff and time for further surgery visits) and costs to patient (based on 456 completed questionnaires)

TABLE IV-Comparison of characteristics of patients having cholesterol tests in surgery by NPT in laboratory during same time (different practices), and in laboratory before surgery tests were introduced

\begin{tabular}{|c|c|c|c|}
\hline & $\begin{array}{l}\text { No (\%) of } \\
\text { patients tested } \\
\text { in surgery }\end{array}$ & $\begin{array}{l}\text { No }(\%) \text { of patients having } \\
\text { laboratory tests (different } \\
\text { general practitioners) }\end{array}$ & $\begin{array}{l}\text { No }(\%) \text { of patients } \\
\text { having laboratory } \\
\text { tests (same general } \\
\text { practitioners as } \\
\text { surgery patients) }\end{array}$ \\
\hline \multicolumn{4}{|c|}{ Drugs prescribed } \\
\hline \\
\hline Lipid lowering & $5 / 126(4)$ & $\begin{array}{c}14 / 124(11) \\
\left(\chi^{2}=4.77, p<0.03\right)\end{array}$ & $\begin{array}{l}5 / 103(5) \\
\text { (NS) }\end{array}$ \\
\hline Antihypertensive & $13 / 126(10)$ & $\begin{array}{c}12 / 123(10) \\
\text { (NS) }\end{array}$ & $\begin{array}{c}14 / 103(14) \\
\text { (NS) }\end{array}$ \\
\hline $\begin{array}{l}\text { Newly prescribed: } \\
\text { Lipid lowering }\end{array}$ & $1 / 126(1)$ & $\begin{array}{c}9 / 124(7) \\
\left(x^{2}=6.8, p<0.009\right)\end{array}$ & $\begin{array}{c}7 / 109(6) \\
\left(x^{2}=4.05, p<0.04\right)\end{array}$ \\
\hline Antihypertensive & $9 / 126(7)$ & $\begin{array}{l}7 / 123(6) \\
\text { (NS) }\end{array}$ & $\begin{array}{l}7 / 109(6) \\
\text { (NS) }\end{array}$ \\
\hline \multicolumn{4}{|c|}{ Risk factors recorded } \\
\hline $\begin{array}{l}\text { All patients } \\
\text { Smoking }\end{array}$ & $\begin{array}{l}126 \\
65(52)\end{array}$ & $\begin{array}{l}125 \\
50(40) \\
\text { (NS) }\end{array}$ & $\begin{array}{c}109 \\
20(18) \\
\left(\chi^{2}=26 \cdot 5, \mathrm{p}<0.001\right)\end{array}$ \\
\hline Weight & $74(59)$ & $\left(x^{2}=6.1, p<0.01\right)$ & $\begin{array}{c}30(28) \\
\left(\chi^{2}=21 \cdot 8, p<0.001\right)\end{array}$ \\
\hline Blood pressure & $95(75)$ & $\begin{array}{c}79(63) \\
\left(x^{2}=3.8, p<0.05\right)\end{array}$ & $\begin{array}{c}62(57) \\
\left(\chi^{2}=8.2, p<0.004\right)\end{array}$ \\
\hline Family history & $44(35)$ & $\begin{array}{c}43(34) \\
\text { (NS) }\end{array}$ & $\begin{array}{c}21(19) \\
\left(\chi^{2}=6.4, p<0.01\right)\end{array}$ \\
\hline Own history & $44(35)$ & $\begin{array}{c}45(36) \\
\left(\chi^{2}=10.4, p<0.001\right)\end{array}$ & $\begin{array}{l}17(16) \\
\text { (NS) }\end{array}$ \\
\hline $\begin{array}{l}\text { Screened patients } \\
\text { Smoking }\end{array}$ & $\begin{array}{l}90 \\
56(62)\end{array}$ & $\begin{array}{l}50 \\
26(52) \\
\text { (NS) }\end{array}$ & $\begin{array}{c}36 \\
7(19) \\
\left(x^{2}=17 \cdot 1, \mathrm{p}<0.001\right)\end{array}$ \\
\hline Weight & $66(73)$ & $\begin{array}{c}26(52) \\
\left(\chi^{2}=5.6, p<0.02\right)\end{array}$ & $\begin{array}{c}12(33) \\
\left(\chi^{2}=15.8, \mathrm{p}<0.001\right)\end{array}$ \\
\hline Blood pressure & $74(82)$ & $\begin{array}{l}38(76) \\
\text { (NS) }\end{array}$ & $\begin{array}{c}22(61) \\
\left(\chi^{2}=5.2, \mathrm{p}<0.02\right)\end{array}$ \\
\hline Family history & $40(44)$ & $\begin{array}{l}24(48) \\
\text { (NS) }\end{array}$ & $\begin{array}{l}10(28) \\
\text { (NS) }\end{array}$ \\
\hline Own history & $36(40)$ & $\begin{array}{l}15(30) \\
\text { (NS) }\end{array}$ & $\begin{array}{c}4(11) \\
\left(\chi^{2}=8.6, p<0.003\right)\end{array}$ \\
\hline
\end{tabular}

Significance of difference compared with surgery tested patients. a mean decrease in practice costs of about $20 \mathrm{p}$ a week ( $2 \mathrm{p}$ per patient investigated) with surgery tests. Associated system costs and patient care costs did not alter significantly: any saving per patient was lost overall because more patients were investigated.

\section{IMPACT ON CLINICAL CARE}

The total number of patients whose records were examined was 369 for cholesterol and 416 for urine. The age-sex distribution of these patients reflected that of the whole population.

The mean cholesterol concentration of patients tested in the surgery $(5.69 \mathrm{mmol} / \mathrm{l})$ was significantly lower than that of patients who had laboratory tests $(6.35 \mathrm{mmol} / \mathrm{l})(\mathrm{p}<0.0001)$ and the proportion taking lipid lowering drugs was higher among the laboratory tested patients (table IV). Cardiovascular risk factors were significantly more likely to be recorded in the medical notes of patients having near patient tests than of those having laboratory tests.

In the six months after the index consultation there were no significant differences between surgery and laboratory tested patients in numbers of repeat or further tests, referrals, or patients taking antihypertensive drugs. However surgery tested patients were significantly less likely than laboratory tested patients to be prescribed a new lipid lowering drug (table IV).

Patients whose cholesterol concentration was high ( $\geqslant 6 \mathrm{mmol} / \mathrm{l}$ ) were compared with those with low concentrations $(<6 \mathrm{mmol} / \mathrm{l})$. Among patients having laboratory tests those with high concentrations were significantly more likely to be referred to hospital and have subsequent lipid testing. No such differences were found for patients having surgery tests.

There were no significant differences in characteristics between patients having near patient and laboratory tests for urinary tract infection. In the six months after consultation patients tested in the surgery were significantly less likely to be referred for urinary tract infection $\left(X^{2}=13 \cdot 1, p=0.0003\right)$ or have further investigations $\left(\chi^{2}=3 \cdot 8, \mathrm{p}=0 \cdot 05\right)$.

Further analysis compared patients tested only in the surgery with those tested only at the laboratory. Symptoms recorded at the index consultation and mean number of consultations in the next six months did not differ between groups. However patients tested in the surgery were significantly more likely to receive an antibiotic at the index consultation $\left(\chi^{2}=3 \cdot 7, \mathrm{p}=\right.$ $0.05)$ and significantly less likely to be investigated $\left(\chi^{2}=7 \cdot 0, p=0 \cdot 008\right)$ or referred $\left(\chi^{2}=5 \cdot 9, \mathrm{p}=0.02\right)$ for urinary tract infection in the following six months.

\section{COST EFFECTIVENESS}

For cholesterol the only measurable benefit was improved medical recording (table IV). The cost per improved record for a practice performing 2.5 tests a week was calculated to be $£ 35.50$; for five tests a week it was $£ 19.30$. For midstream urine analysis the fewer investigations and referrals in the subsequent six months are estimated to produce annual savings of $£ 1150-2450$ per practice.

\section{CONTINUED USE}

At the end of the study practices were given the option of retaining the testing equipment. No practice retained the machines for measuring electrolytes or chlamydia testing kits. The urine dipstick readers were retained by all the practices and the Reflotron analysers by all but one of the practices.

\section{Discussion}

In this study of surgery based near patient testing we could not impose uniformity on process of care, and each practice operated differently. The result is a 
pragmatic evaluation which has greater applicability to the real health service.

The overall investigation rate for the baseline phase (144/1000 consultations) was $16-80 \%$ higher than that reported from general practice studies in Belfast, London, ${ }^{10}$ and Manchester. ${ }^{11}$ The number of investigations requested by general practitioners has been increasing in recent years, ${ }^{12}$ both in absolute numbers and as a proportion of the laboratory total. Our findings are consistent with this trend.

The study design enabled us to look for trends with time as well as the effects of surgery based tests. For cholesterol, the availability of the surgery based testing seemed to enhance a strong trend towards increased testing, almost certainly augmented by the effects of the 1990 contract for general practice. In comparison there was a $10 \%$ reduction from baseline in use of laboratories for midstream urine analysis when the near patient test was not available.

Our results show generally low levels of uptake, even though the test equipment did not cost the practices. This is consistent with the findings of Hailey $e t$ al in an Australian general practice study, ${ }^{13}$ and Hobbs et al in Britain. ${ }^{14}$ Nevertheless, the impact of surgery based testing on general practitioners' traditional use of laboratories also needs to be considered. Is near patient testing used instead of laboratory tests, as extra tests, or as both? Since there was only a small increase in laboratory cholesterol testing, the $88 \%$ increase in tests when near patient testing was available suggests that it was used as an extra test. For midstream urine, however, the increase in testing overall was mainly due to patients having both laboratory and near patient tests.

We thought that general practitioners might use near patient tests more often than laboratory tests for monitoring chronic conditions and following up acute conditions. ${ }^{15}$ This seemed to be true only for the electrolytes test, where $58 \%$ of near patient tests were used for monitoring compared with $34 \%$ of the laboratory tests. For cholesterol the proportion of near patient tests used for monitoring was actually lower, with strong evidence of selected use of these tests for screening.

Our results indicate that widespread introduction of near patient testing equipment into the surgery for clinical tests could greatly increase investigation costs in general practice. For example, equipment for cholesterol tests, even if confined to practices with more than 9000 patients, might generate annual increases of $£ 3.3 \mathrm{~m}$ to $£ 4.9 \mathrm{~m}$. The exception is testing for urinary tract infection. Although near patient testing had little impact at the practice level on costs, patients tested in the surgery had fewer subsequent investigations and referrals. Even if half of this effect were due to unidentified differences between patient groups (we

\section{Practice implications}

- Commercial pressures are being put on general practitioners, particularly fundholders, to buy equipment for clinical tests

- The cost effectiveness of near patient testing has not been evaluated in general practice

- In this study, introducing near patient testing had no overall effect on use of tests

- Cholesterol testing increased greatly but resulted only in better recording of risk factors for coronary heart disease

- Midstream urine analysis was the only near patient test that was cost effective

found no clinical differences recorded at the index consultation) national savings of $£ 2.9 \mathrm{~m}$ to $£ 6.2 \mathrm{~m}$ would be predicted after widespread introduction of equipment for midstream urine analysis into general practices.

The introduction of surgery based near patient diagnostic tests needs to be considered carefully as, with the exception of midstream urine analysis, it may increase costs without producing extra benefit.

1 Hilton S. Near patient testing in general practice: a review. Br 7 Gen Pract 1990;40:32-6.

2 Freeman G. Desktop laboratory technology for general practice. $\mathrm{Br} \mathcal{F} \mathrm{Gen}$ Pract 1992;42:311-2.

3 Jennett $B$. Health technology assessment. The rule should be no evaluationno technology. BMF 1992;305:67-8.

4 Office of Technology Assessment. Medical technology and costs of the Medicare program. Washington DC: US Government Printing Office, 1984:41-53.

5 Szczepura A. Rush to arms; how cost-effective are new additions to the clinician's armoury? Health Service fournal 1992;102:20-2.

6 Banta HD (Chairman). Anticipating and assessing health care technology. A report commissioned by the steering committee on future health scenarios. Netherlands: Martinus Nijhoff, 1987.

7 Tidal Wave. New technology, medicine and the NHS. London: Kings Fund Centre, 1992.

8 Guyatt G, Drummond M, Feeny D, Tugwell P, Stoddart G, Haynes RB Bennett K, Labelle R. Guidelines for the clinical and economic evaluation of health care technologies. Soc Sci Med 1986;22:393-408.

9 Mills KA, Reilly P. Laboratory and radiological investigations in general practice. I. Type requested and rate of use. BMf 1983;287:1033-6.

10 Hartley R, Charlton J, Harris C, Jarman B. Influence of patient characteristics on test ordering in general practice. $B M \mathcal{F}$ 1984;289:735-8.

11 Wilkin D, Metcalfe DHM, Hallam L, Cooke M, Hodgkin PK. Area variations in the process of care in urban general practice. $B M 7$ 1984;289:229-32.

12 Batstone G, Firstbrook A. Symposium on factors affecting decisions in general practice use of pathology services. Office of Health Economics 1990;April practice

13 Hailey DM. Office pathology testing in Australia. Labmedica 1989; July:16-25.

14 Hobbs FDR, Broughton PMG, Kenkre JE, Thorpe GHG, Barki A. Comparison of the use of four desktop analysers in six urban general practices. Br f Gen Pract 1992;42:317-21.

15 Drury $M$. Symposium on factors influencing clinical decisions in general practice: use of diagnostic facilities. Office of Health Economics 1990 April 23:38-40.

(Accepted 15 fuly 1993) 